\title{
The Schools and Pre-Medical Studies
}

$I^{\mathrm{N}}$ N Nature of July 20, 1935 (136, 90), appeared an article upon the recent report on the medical curriculum* dealing with the report from the point of view of clinical studies, but making no reference to the pre-medical studies and their relation to the work carried on in public and other secondary schools. The present article, which deals with this section of the report, is intended to be supplementary to that previously published.

The third section of the report deals with the pre-medical studies and may be briefly summarised as follows :

1. The period of pre-medical studies is spent with increasing frequency at school and only too often general education is stopped at too early an age in order to permit specialisation in science for passing the pre-medical examination.

2 . In some cases, this has resulted in the formation of small groups working solely for this object, and thus segregated some, not only from the rest of the school, but even from other boys studying science.

3. The early specialisation is undesirable and could be avoided if a reasonable proportion of time was spent on science throughout the school period.

4. Greater use should be made of the Higher School Certificate examinations as a means of obtaining exemption from the First M.B. examination.

5. A common syllabus in chemistry, physics and biology is desirable for all First M.B. examinations, and suggestions for such a syllabus are given in the appendix to the report.

6. To ensure sufficient time for general education, and to avoid too early specialisation, medical studies proper, that is, anatomy and physiology, should not be begun before the age of eighteen.

It appears desirable to examine these criticisms and the suggestions, and to do so it is necessary to review briefly the work carried on in public and other secondary schools at the present time.

In the majority of schools, the work of the pupil is directed to attaining the standard of a School Certificate examination at the age of $15-16$ years, and up to this stage in most schools there is little or no specialisation, each pupil commonly offering English, at least one other language, elementary

* Report of the Conference of Representatives nominated by the Universities of Oxford, Cambridge and London, the Royal College of Physicians of London, the Royal College of Surgeons of England, and the Society of Apothecaries of London on the Medical Curriculum. Pp. ii +34 . (London: University of London, 1935.) 18. mathematics, and from two (minimum) to five (maximum) additional subjects, usually including some science subjects.

A large number of pupils leave school when they have passed the School Certificate examination, but those intending to study medicine stay for an additional one or two years, and naturally their academic interests are centred mainly on their first professional examination. If these candidates have offered chemistry and physics (and possibly biology) for the School Certificate examination, and assuming they are about 16 years of age, it should be a matter of comparative ease for them to reach the standard of the First M.B. examination at the end of a further two years work without any intensive preparation, and the formation of special M.B. classes appears quite unnecessary.

Unfortunately, there are frequently complications so far as individual pupils are concerned. For some reason, it may be ill-health, slower development, or failure to pass the School Certificate examination at an earlier attempt, a pupil may already have reached the age of 17 years before becoming a post-certificate student. The tendency then will be for him to endeavour to pass his First M.B. examination at the end of a further year's work, a proceeding which must entail some intensive preparation and which probably segregates him to some extent from the rest of the science students.

In large schools, there is often also the difficult problem of a boy, who, having spent his time on the classical or modern side up to School Certificate stage, decides to study medicine. He has probably done little or no science, but is now transferred to the science side, and the problem becomes one for the science masters. To expect the boy to work with students of the science side who have already spent about three years working at science subjects is unreasonable, and therefore a special course of study has to be planned for him. Since this boy is endeavouring to pass in two years (or in extreme cases in one year) the same examination over which the preparation of the science side student has taken four or five years, the course of study is necessarily intensive, and demands all the time of the student, and even then the knowledge gained is in many cases superficial, and the examination is passed through the cultivation of a retentive memory rather than of scientific method. The general education of such a student must suffer, and if there is more than one pupil in such 
an unhappy position, it is easy to see how special M.B. classes arise.

As the report points out: "If all schoolboys and girls devoted a reasonable proportion of their time throughout the school period to the natural sciences there should be less need for a prolonged period of intensive preparation at the end of school life".

Putting on one side the special cases considered in the preceding paragraphs, one may now inquire : What provision is made for the continuation of the general education of post School Certificate students? Some specialisation is now inevitable, and as the report states "may not be undesirable", for those remaining at school usually have some definite objective, either a professional examination or a university scholarship, and the general work of these students is usually directed towards a Higher School Certificate examination. In this, a candidate is required to satisfy the examiners in a particular group of studies, for example, classical studies, modern studies, mathematics, or natural sciences, but, in addition, he has also to satisfy the examiners in at least one subsidiary subject which is quite outside the group in which he has specialised. This avoids, to some extent, undue specialisation, and it is probably in recognition of this fact that "the Conference would, however, approve of greater use being made of the Higher School Certificate Examinations as a means of obtaining exemption from the Examinations for the lst M.B. or Basic Sciences".

Here again arise difficulties which could easily be removed. In some cases, a university will not recognise the possession of the Higher School Certificate of another university for exemption from the First M.B. examination. To take a definite illustration, a boy attending a school taking the Oxford and Cambridge Joint Board examinations can obtain exemption from London Matriculation by a suitable School Certificate of the Joint Board, but finds that he has no means of gaining exemption from the First M.B. examination at London by the Higher Certificate of the Joint Board, and his easiest course is to work for the First M.B. examination. There is no incentive for him to work at subjects other than the science subjects of the First M.B. and therefore his general education virtually ceases. If greater recognition was given by all universities to Higher School examinations for purposes of exemption from their own examinations, difficulties such as these could be avoided.

The need for a common syllabus for all First M.B. examinations has long been apparent to teachers who have been faced with the prepara. tion of individual members of the same class for different First M.B. examinations. The difficulty may be made clearer by a consideration of the biological syllabuses of the First M.B. examinations of Cambridge and London. Since the introduction of the new syllabus in 1935 into the Cambridge examination, there is more in common than there was formerly. Thus in each syllabus the following types are mentioned: Amoeba, Monocystis, Paramecium, Lumbricus, Scyllium, Rana, Lepus; Spirogyra, Pythium, Saccharomyces and Bacteria. Peculiar to London are Obelia, Homatococcus, malarial parasite amd the flower structure of Lilium and Pisum; and to Cambridge : Chlamydomonas, Protococcus, Polytoma, Pandorina, Eudorina, Volvox, Fucus, Hydra, cockroach, and frog embryology: Truly, as is stated in the report, "the training would be more efficient if these differences, none of them great or important, could be removed".

Appendix A of the report presents a suggested common syllabus for the subjects of the First M.B. examination. It may not be out of place at this point to pause and consider the proposed syllabuses. In the preparation of the report, the representatives consulted various authorities from medical schools, and also headmasters and representatives of the Science Masters' Association; and it may be assumed that pre-medical studies were fully discussed, and the syllabuses given in Appendix A are the outcome of those discussions. The standard of work outlined by the syllabuses appears to be roughly that of the present First M.B. examinations, that is, somewhat lower than that of the Higher School Certificate examination in the separate subjects. This is probably wise, for whilst it will allow a candidate who has offered science subjects in the School Certificate examination to take his First M.B. examination with fair prospects of success at the end of a further year's work (a benefit to the older post-School Certificate student already referred to), it will probably require two years' careful work from a candidate who has previously done little or no science, unless he is 'crammed' for this particular examination, a deplorable event, but practically impossible to eradicate, since parents' wishes must be respected.

If the recommendation that medical studies proper should not be begun before the age of 18 years is carried into effect, then there will be little incentive for the post-School Certificate student of 16 years to take the First M.B. examination the following year, and he can continue the normal school course for a further two years and attain the somewhat higher standard required from Higher School Certificate candidates, providing his success will gain for him exemption from the First M.B. examination. The syllabuses will probably be well received by teachers, to whom the 
adoption of the syllabus by all authorities is of greater importance at the present moment than the details of the contents.

It may be predicted, therefore, that the recommendations of the report so far as they are concerned with the pre-medical studies and the age for commencement of medical studies proper will receive the enthusiastic support of teachers in public and other secondary schools. If the recommendations are carried into effect, the complaints of undue specialisation and too low a standard of general education will largely disappear, and the medical students produced by the schools may be better fitted to "acquire that kind of culture which survives the forgetting of facts".

W. J. R. D.

\section{Geology as a School Subject}

$A^{\mathrm{T}}$ the Norwich meeting of the British Association, a discussion was held in Section C (Geology) on "Geology in Schools". It was certainly appropriate that this subject should be discussed during the year in which Prof. W. W. Watts is president of the Association, for during a period of more than thirty years he has repeatedly pressed the claims of geology as a school science subject, and his presidential address to Section C in 1903 dealt comprehensively with the functions of geology in education. For various reasons, little progress has been made with the introduction of the subject into schools, although in the meantime there has been a great extension of science teaching.

The Norwich discussion may be summarised the more easily since it revealed a remarkable unanimity of opinion, practically all who spoke emphasising their agreement with the previous speakers. It was keenly felt that geology does not occupy the place to which it is entitled in the educational system, in schools, universities or in the wider field of adult education. Dr. A. K. Wells showed that the number taking geology in the University of London General Schools Examinations has fallen almost to zero. On the other hand, many speakers emphasised the fact that geology proves one of the most attractive sciences when once a student is introduced to it. As Prof. Watts said: "there are many types of mind to whom this science appeals as no other one does": it gives a new interest which frequently lasts beyond school days, and which gives meaning to every piece of country visited, an important fact in these days of wider travel. Prof. P. G. H. Boswell stressed the value of geology as a cultural subject, and quoted Mr. Ramsay MacDonald's statement that "if any one of the sciences were selected as the key to all the other sciences-as that which in its subject-matter and its history, the history of its evolution, enforces the true scientific methodgeology might be selected as that science".

In the course of the discussion, many advantages of geology as a school subject were touched upon.
Among these the most important appears to be that geology is perhaps the very best training ground in the collection and co-ordination of observed facts. It was also emphasised that the equipment necessary for teaching (more abundant and more easily obtained now than at any time) is probably less expensive than in any other science. Many rural schools are situated in areas which can be described as natural laboratories, and it is preposterous that scholars do not learn something of the meaning of these surroundings. On the other hand, Dr. H. D. Thomas referred to the valuable work in geology done in a London school, so that the teaching of the subject by no means needs to be confined to rural areas. Prof. A. Hubert Cox spoke of the excellent work now being done in some Welsh schools, and Mr. A. N. Thomas gave an account of the courses provided at Caerphilly.

It was also pointed out that in several sciences taught in schools the teaching has become increasingly dogmatic: even the experiments performed are "carefully designed to eliminate all confusing and collateral elements". At least some teachers of chemistry and physics consider that the elementary parts of those subjects must be mastered as quickly as possible, and that it is impossible for a student until he approaches the standard of an honours graduate to begin to assess for himself the real value of experimental evidence or to develop his originality and critical ability. There is a real danger that a pupil finishing his science training in school may have acquired a vast body of scientific information, but may have had little chance of developing that scientific outlook which is likely to make him a more valuable member of most communities. In geology, on the other hand, it is still possible for a beginner to feel the excitement of making new discoveries; a fossil or a dip observation in a temporary section may be vitally important. The co-ordination of such observed facts, and the examination of alternative hypotheses concerning which the 